\title{
Distress and BSE Realty Sector: Pre \&t Post Covid Analysis
}

\author{
Arpita Agarwal', Ity Patni', Somya Choubey² and Nishu Gupta \\ ${ }^{1}$ Department of Business Administration, Manipal University Jaipur, India \\ ${ }^{2}$ Department of Commerce, Manipal University Jaipur \\ ${ }^{3}$ Department of Business Administration, Manipal University Jaipur \\ Corresponding author email: ity.patni@jaipur.manipal.edu
}

\begin{abstract}
Purpose: This article interprets the pre-epidemic scenario and analyzing the impact of Coronavirus Outbreak on Indian Realty Sector along with testing the efficiency of Zmikskwi distress prediction model during crisis on the financials of BSE SEP Realty Sector. The study is based on the various reports on real estate sector performance and financial statements of the companies of Realty Index listed on the Bombay Stock Exchange (BSE) during a period of five years since demonetization till the year outbreak bursted, i.e 2016-2020. For forecasting the financial health of the realty sector companies during the scenario, the distress prediction model Zmijewski is used. This provides us the direction whether model can predict the distress in advance so that investors could be alarmed before time. The Universal economic downturn coupled with coronavirus pandemic might have more adverse effect on real estate demand in the country this year. Our empirical findings on the prediction model suggests that Zmijewski model has a remarkable accuracy of prediction even in hard times during from 2016-20, as per interpretation realty companies are coming in distress zone on the basis of the threshold of the model, which can be used as a caution bell to avoid the losses before investing hard earned money in financially unsound companies. To the author's knowledge, it is anticipated that this study will be the most extensive to-date review in this field of literature to analyze the pre-pandemic scenario with the post impact of the COVID-19 pandemic on Real estate sector. Additionally, this study uses distress prediction model to test its efficiency and rings the caution bell for the investor before taking investment decisions during this period.
\end{abstract}

KEY WORDS: COVID-19, REAL ESTATE, FINANCIAL DISTRESS, ZMIJEWSKI MODEL, DISTRESS PREDICTION.

\section{INTRODUCTION}

The Coronavirus pandemic has put halt on everyone's societal and gainful life. During this period, countries are facing multiple shocks: majorly economic and health shocks. The first case was observed in Wuhan (China) in the month of December, 2019 and it speedily rolled out throughout the world. In our history so far, this is considered as one of the immense health crisis. In India, it was January 30, 2020 when the very foremost case

Biosc Biotech Res Comm P-ISSN: 0974-6455 E-ISSN: 2321-4007

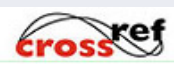

Identifiers and Pagination

Year: 2021 Vol: 14 No (9) Special Issue

Pages: 28-32

This is an open access article under Creative

Commons License Attribn 4.0 Intl (CC-BY).

DOI: $h t t p: / / d x$.doi.org/10.21786/bbrc/14.9.7 and symptoms of this virus was detected. From the beginning to till date, the counting of infected persons are enormously increasing day on day leaving the country helpless with no vaccines till date in the hands with just one way out i.e isolation and distance from other people to block the spread of COVID virus. Due to this, economic activities of the nations are facing major downfalls (Chaoudhary, 2020). It has also sparked fears of an impending economic crisis and recession (S. Mahendra Dev, 2020). Almost all sectors got affected in this crucial period where everybody is counting the notion such as 'survival of the fittest'. Majorly production and the service sector like tours and travels, hotels, healthcare, real estate, IT and banks have faced a massive hit. It leads to giant layoffs, leaving the companies with no options other than bankruptcy as their profitability and liquidity got affected directly (Amankwah-Amoah, 2020).
Article Information

Received: $12^{\text {th }}$ Apr 2021

ccepted after revision: $18^{\text {th }}$ June 2021 
The real estate sector is considered as one of the prime retaining sectors, just after agriculture in the country. But, this sector is going through extrinsic strain during couple of years due to lack of liquidity, lower demands, downfall in consumptions, price drops and accelerating NPA's frightening their survival and growth during the crisis. This pandemic is considered as a third black swan for realty sector after demonetization and implication of RERA and GST in 2017. After accepting all the tremendous challenges, it started glowing in 2018 but in 2019 global economic downturn with steady GDP growth affected this sector again.

The pandemic has pushed and increased the numbers of recently financially unsound companies. It is determined that around "half a million firms are at risk of collapse" (Cook \&t Barrett, 2020). Like, India Bulls Real Estate finalized its merger plan with embassy group and the proposed amalgamation will see the company exit from real estate business completely (economictimes. indiatimes.com, August 2020). (Walsh, 2020) concluded that, "large and small companies, are succumbing to the effects of the coronavirus", and 2020 has been projected to "set a record for so-called mega bankruptcies". This results in economic distress leaving its abiding impact on world economies. Policymakers, analysts and authorities have become progressively anxious about the antieffects of COVID-19 on business traits, industry reforms and on the global economy. With the recent news on stocks of BSE realty, Prestige Estates, Sunteck Realty, Brigade Enterprises, and India Bulls real estate etc., top performers are now coming in the list of top losers of the index.

Plenty of firms have closed their activities around the world due to financial anguish during the crisis (Wagas, 2018). The inflated production costs, declining sales activities, financial weakness, managerial defeat, or blend of these reasons are alarming bell for a company for financial illness (Shankar, 2013). Forecasting distress is one of the challenging tasks for all organizations all over the world in this current situation of pandemic (Awais, Hayat, et al., 2015). There is a huge demand to predict the financial distress at early stage to avoid failures. To prevent the risk of losing investments, investors always intend to predict the financial soundness of the corporations. Present study gives out the perception of the Pre-pandemic realty sector and examines the crash due to COVID-19 on real estate industry. Further it tests the efficiency of the Zmijewski (1984) distress prediction model on the financials of S\&P BSE realty sector companies for a period of five years during the hit of demonetization, RERA and health crisis i.e from 2016-2020.

\section{Objectives}

1. To study the performance of Indian realty sector before Covid-19 pandemic.

2. To understand the impact of Coronavirus outbreak on Indian Real estate.

3. To test the efficiency of Zmijewski distress model during the period.

\section{RESEARCH METHODOLOGY}

Annual reports were checked to collect the data of this study which is on BSE Realty Sector over the period of five years right from demonetization to pandemic. Other authentic websites of Money control, Bombay Stock Exchange and Stock Screener etc. were also used to get the missing secondary data. Further, reports on real estate sector from various research firms are considered like JLL Research, Anarock, and FICCI etc. during the pandemic. To forecast the financial health of the companies, the distress prediction model Zmijewski is used. The drawn out data was then put into the equation of the stated model. This provides us with a view if model was able to predict the distress during the period. The sampled companies taken under consideration are shown in Table 1.

\begin{tabular}{|c|c|c|}
\hline Delhi Land and Finance (DLF) & Sobha Limited & Brigade Enterprises Ltd \\
\hline Godrej Properties Ltd & The Phoenix Mills Ltd & \\
\hline Prestige Estates Projects Ltd & Sunteck Realty Ltd & Mahindra Life space Developers Ltd \\
\hline India bulls Real Estate Ltd & & Oberoi Realty Ltd \\
\hline
\end{tabular}

The formula, description and score categorization of Zmijewski model are given underneath:

Zmijewski (1983): $Z=-4.3-4.5 X 1+5.7 X 2-0.004 X 3$

(Zmijewski, M. E. (1984)

$\mathrm{ZS}=$ Zmijewski Score

$\mathrm{X} 1=\mathrm{ROA}$ (Net Income/ Total Assets)

$\mathrm{X} 2=$ Leverage (Total Liabilities/Total Assets)

X3 = Liquidity (Current assets/current liabilities)
Financial Data Analysis And Interpretation: Zmikskwi model formula applied on 10 real estate companies from the list of BSE S\&P Realty sector in Table 3.

When the appropriate coefficient values are multiplied with the various assigned ratios, the final Zmikskwi value is determined after summing the results. From Table 3, it can be inferred that financial performance of these companies during the period of five years is not sound and prominently all the companies are lying in Distress Zone (as per the threshold of the model shown 
in Table 2) due to the effect of Demonetization, RERA and COVID pandemic. The Zmijewski Value of all these companies are coming $>0$ in all the years from 2016-2020 which shows that there is more probability for financial embarrassment in near future.

Table 2. Threshold Values of the Model

\begin{tabular}{|c|c|c|}
\hline Scores & Zone & Results \\
\hline $\mathrm{ZS}<0$ & Healthy & Protected \\
\hline $\mathrm{ZS}>0$ & Distress & $\begin{array}{c}\text { Not Stable, Likely } \\
\text { to face financial distress. }\end{array}$ \\
\hline
\end{tabular}

Table 3. $\mathrm{Z}$ value of BSE S\&P Realty Sector Companies (2016- 2020)

\begin{tabular}{|c|l|c|c|c|c|}
\hline \multicolumn{1}{|c|}{ Companies } & 2020 & 2019 & 2018 & 2017 \\
\hline SR No & \multicolumn{1}{|c|}{ Z value } & Z value & Z value & Z value \\
\hline 1 & Delhi Land and Finance (DLF) & 1.06 & 1.27 & 1.33 & 1.26 \\
\hline 2 & Godrej Properties Ltd & 1.12 & 1.10 & 1.15 & 0.95 \\
\hline 3 & Prestige Estates Projects Ltd & 1.23 & 1.17 & 1.22 & 0.90 \\
\hline 4 & India bulls Real Estate Ltd & 1.45 & 1.34 & 1.40 & 1.38 \\
\hline 5 & Sobha Limited & 0.87 & 0.78 & 1.10 & 1.18 \\
\hline 6 & The Phoerix Mills Ltd & 1.21 & 1.17 & 1.18 & 1.20 \\
\hline 7 & SunTeck Realty Ltd & 1.17 & 0.97 & 1.06 & 0.59 \\
\hline 8 & Oberoi Realty Ltd & 1.16 & 1.03 & 1.01 & 1.03 \\
\hline 9 & Brigade Enterprises Ltd & 1.11 & 1.13 & 1.18 & 1.11 \\
\hline 10 & Mahindra Lifespace Developers Ltd & 2.07 & 1.24 & 1.26 & 1.27 \\
\hline
\end{tabular}

Impact Of Covid Pandemic On Realty Sector: In the Indian context, the impact of this coronavirus pandemic seems damaging. It has affected the realty sector massively which was already going through the clump of challenges after the fortnight demonetization, RERA reforms and policies and then promulgation of GST in 2017. Towards the sectors growth, residential, commercial, and retail are the key major contents which are furnishing immensely. With reference to JLL research report, Real estate was contributing approximately 6\% to India's GDP in 2017 and this number was expected to grow to $13 \%$ by the year 2025 as per projection growth trends but with the massive hit by the pandemic on the country, the national GDP plunging into negative figures which will result in economic recession. As during financial crisis in 200708, GDP faced a massive decline from 7.77\% to 3.09\% in the year 2008-09. Similarly, after demonetization again the giant decline fall was noticed in year 2016-17 (shown in Figure 1) coupled with the Covid pandemic it largely falls to 5\% in FY 2019-20 and expected to go more downstream in FY 2020-21.

With reference to Anarock research report, the market magnitude of the industry was $\$ 120$ billion in 2017 and was expected to arise to $\$ 650$ Billion by 2025 and $\$ 1000$ Billion by 2030 (Shown in Figure 2) which has now become a dream in this current critical situation. Not just this, if we compare the sales of residential units with the previous corresponding quarter the decline of 29\% is noticed in Q1 2020 (Shown in Figure 3) which is the highest downfall till now. Additionally, a fall of 40\% in new completions was recorded in the first quarter of
2020 (Shown in Figure 4). FDI inflows in the upcoming quarter of the present year may have more diminishing trend in this sector. Realty sector creates vast opportunity for both skilled and unskilled workforce. It successfully managed to give employment to 40 million people in the year 2013, which tremendously rose to 52 million in 2017 and was expected to touch the figure of 67 million by the end of 2022. However, this target seems difficult to accomplish in near future with this ongoing pandemic. It seems to be a giant dip of 30\% in Net absorption (Shown in Fig 5). Furthermore, the banks have decided to cut the policy rates to deal with the current situation, RBI cuts the repo rate bringing it down to 4.4\% in March, 2020 which will also result in a decline of home loan rates.

Figure 1: GDP growth rate highest declining trend during COVID-19 pandemic.
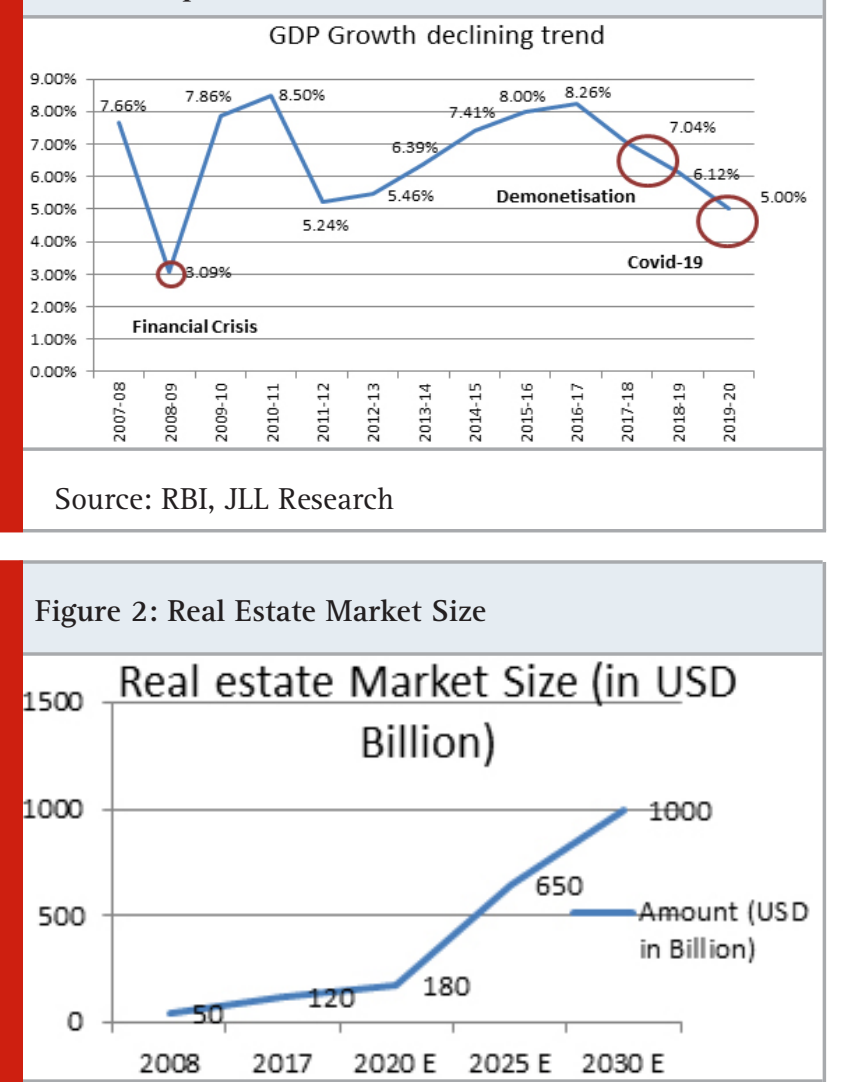

Figure 3: Housing Sales Downfall Compared to Previous Corresponding Quarter

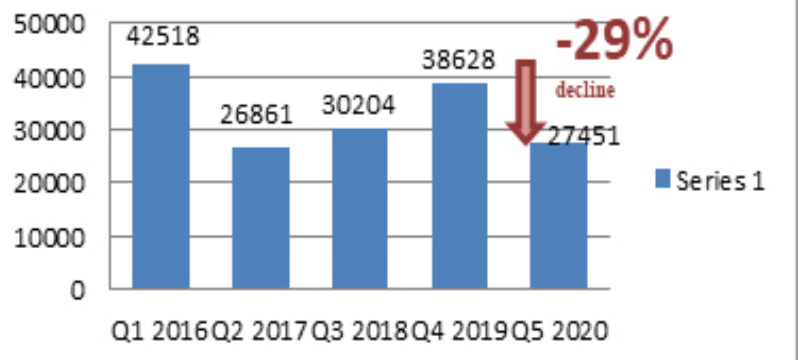

Source: Real Estate Intelligence Service(REIS), JLL Research 
Figure 4: New Completion Enormous decline hit during Pandemic

\section{New Completions (million sq ft)}

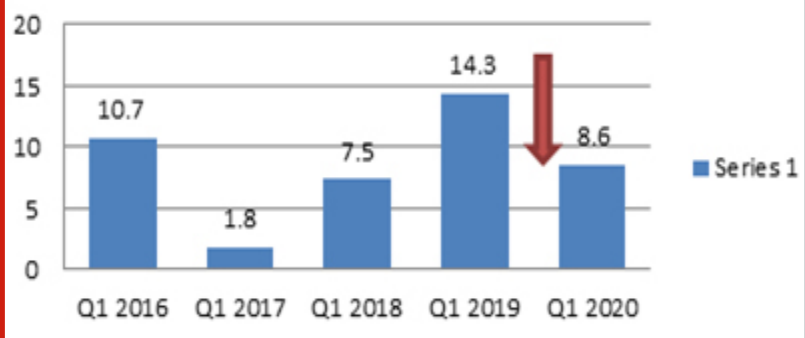

Source: REIS, JLL Research

Figure 5: Giant dip in Net Absorption (Million Sq Ft)

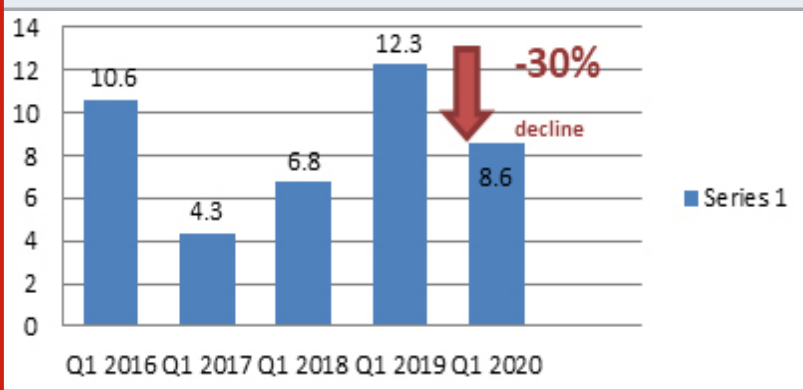

Source: Real Estate Intelligence Service(REIS), JLL Research

\section{Suggestions}

Adaption of Technology: Real estate as an industry must do a lot of catching up on technology, and this crisis making things develop even more quickly. Physical distancing and the lockdown of physical spaces have magnified the importance of digitization. After this situation is over, these technologies which enable more efficient operation and communication will be as an essential element of a good organization.

Risk Management Practices: Practises and policies pertaining to risk management need to be taken seriously by all businesses and not be restricted to the financial sector. It needs to be practised with all earnestness to prepare the preparedness for any future disaster and ability to mitigate situation.

Focus on Liquidity and cash flow management: Cash is King- understand your cash and working capital needs. During this crisis, establishing the correct cash flow management mechanism is pivotal for property developers to ensure effective overall planning and adequate liquidity to avoid shortage in capital and a possible debt crisis. Early crisis signals and indicators may help developers to create their own management mechanism.

Business Continuity Planning: The pandemic has created a serious threat to people, business and economies around the global. Existence and longevity of the business in the current scenario is crucial. Management must focus on how they can protect their people, serve to their customers and steady their business continuity. All the pre framed policies and regulation needs a quick change to adopt the changes in environment and brace them in the light of the prevailing pandemic situation.

Focus on Online presence and transactions: In the current era of social distancing, people familiar with e-commerce will surely wins the game. As the customers are shifting more towards electronic mode for their day to day activities rather than physical presence to cut the community of virus. In this dynamic environment, all the businesses are facing rapid changes with innumerable challenges and real estate is no different. The real estate players must adapt digitalization to survive in the market. They must bring innovative digital ideas and initiatives to engage with their customers and prepare to take them towards e-tour of properties.

Limitations and Future Scope of the Study: The study is limited to the footprint of COVID-19 on Real estate sector based on the published reports and financial statements of the company of five years taken from 20162020. Further studies can be extended considering other dynamic sectors with larger data sets using alternative modeling techniques, assessing, and comparing the outcomes of different models by taking multiple samples of the sectors at the same time.

\section{CONCLUSION}

It might be just the beginning; industries must prepare themselves for much more drastic terrible effect of this pandemic. All the industries including realty sector have to innovate and amend their essential flaws to hit the crisis. Sit and observe strategy, will not going to work for realty sector during this time. It must adapt the rapidly changing environment. This is one of the few studies focused on the impact of Coronavirus outbreak on business arena of Indian realty sector. Further, this study investigated the efficiency of Zmikskwi model during the crisis to examine the financial soundness of the BSE SCtP realty companies. It is assumed that with every threat, there is always an opportunity to grow and fly high and believe to shine in near future. Indian retail sector will also flourish and embark the different growth path in the coming years with its strong hands on technology and media with viable business models. Collaterally, this study suggests the most effective and accurate model for playing safe in the future.

\section{REFERENCES}

Agrawal, A. (2020). Sustainability of airlines in India with Covid-19: Challenges ahead and possible way-outs. Journal of Revenue and Pricing Management, 1-16. Albers, S., \& Rundshagen, V. (2020). European airlines $\bigotimes$ strategic responses to the COVID-19 pandemic (JanuaryMay, 2020). Journal of air transport management, 87, 
101863.

Amankwah-Amoah, J. (2020). Stepping up and stepping out of COVID-19: New challenges for environmental sustainability policies in the global airline industry. Journal of Cleaner Production, 271, 123000.

Awais, M., Hayat, F., Mehar, N., \&t Waqar-ul-Hassan. (2015). Do Z-Score and current ratio have ability to predict bankruptcy? Developing Country Studies, 3036.

Baldwin, R., \&t Weder di Mauro, B. (2020). Economics in the Time of COVID-19.

Chaudhary, M., Sodani, P. R., \&t Das, S. (2020). Effect of COVID-19 on Economy in India: Some Reflections for Policy and Programme. Journal of Health Management, 22(2), 169-180.

Chava, S., \&t Jarrow, R. A. (2004). Bankruptcy prediction with industry effects. Review of Finance, 8(4), 537569.

Del Giudice, V., De Paola, P., \&t Del Giudice, F. P. (2020). Covid-19 infects real estate markets: Short and mid-run effects on housing prices in Campania region (Italy). Social Sciences, 9(7), 114.

Dev, S. M., \&t Sengupta, R. (2020). Covid-19: Impact on the Indian economy. Indira Gandhi Institute of Development Research, Mumbai April.

Husein, M. F., \&t Pambekti, G. T. (2015). Precision of the models of Altman, Springate, Zmijewski, and Grover for predicting the financial distress. Journal of Economics, Business, \&t Accountancy Ventura, 17(3), 405-416.

Imanzadeh, P., Maran-Jouri, M., \&t Sepehri, P. (2011). A study of the application of Springate and Zmijewski bankruptcy prediction models in firms accepted in Tehran Stock Exchange. Australian Journal of Basic and Applied Sciences, 5(11), 1546-1550.

McAleer, M. (2020). Prevention is better than the cure: Risk management of COVID-19.

Miyakawa, D., Oikawa, K., \& Ueda, K. (2020). Firm exit during the covid-19 pandemic: Evidence from japan. Research Institute of Economy, Trade and Industry (RIETI).

Pavlovic, V., Muminovi邓, S., \&t Cvijanovi邓, J. M. (2012). Adequateness of applying the Zmijewski model on Serbian companies. Industrija, 40(4), 25-39.

Zmijewski, M. E. (1984). Methodological issues related to the estimation of financial distress prediction models. Journal of Accounting research, 59-82. 